\title{
Eliana Romanelli*
}

eliana.r@hotmail.it

orcid.org/0000-0002-8002-3258

ASGP - "Federico Stella" Graduate School of Criminal Justice

Università Cattolica del Sacro Cuore

1 Largo Gemelli

20123 Milan, Italy

\section{Photographs as "Cultural Property" under Italian and European Union Law: A Complex Picture ${ }^{1}$}

\begin{abstract}
Photography has only recently come to be considered, besides being a creative work protected under copyright law, also as a possible element of "cultural heritage". Even in Italy, with its traditionally pervasive regulation of cultural property, while the issue was raised in the 1970s it only entered the legal framework on cultural heritage in the 1990s. During the same period, photographs began to be considered as "cultural goods" under the European legal framework, albeit with mixed attitudes. This article provides a summary of this legal evolution, including an analysis of possible effects of the 2017 reform of Italian cultural property export law on this specific area, and discussing the impact of current regulation on the photography market.
\end{abstract}

\footnotetext{
* Eliana Romanelli is junior teaching assistant of Law \& the Arts in the Università Cattolica del Sacro Cuore (UCSC) of Milan, Italy, where she is also a member of the research group on offences against cultural heritage of ASGP - "Federico Stella" Graduate School of Criminal Justice. She has a Second Level Professional Master Degree in Arts Management and is currently a lawyer in the Art Law Department of the law firm NCTM in Milan.

1 This article builds on the presentation given, together with Arianna Visconti (whose article in this issue of the "Santander Art and Culture Law Review" is meant as complementary to the current essay), at the Third All Art and Cultural Heritage Law Conference. "National Treasures": Limits to Private Property and Cross-Border Movements, held at the University of Geneva on 10 November 2018. The underlying research was partly funded through the D.1.2012 programme of the Università Cattolica del Sacro Cuore, as part of an ongoing research on "Emerging Criminal Trends and New Prevention Strategies: Cultural Property Trafficking".
} 


\section{GENERAL ARTICLES}

Eliana Romanelli

Keywords: cultural heritage law, criminal law, Italian and EU law, legal definitions of cultural property, photographs as cultural property, art market, photography market

\section{Introduction: How Photography Became an Art Form}

For decades artists and critics have debated whether photography can be considered as art. From the beginning, when the photographic process of Louis Jacques Mandé Daguerre was granted a patent by the Academy of Sciences in Paris in 1839, artists were dismissive of photography, and saw it as a threat to "real art". During a demonstration of the daguerreotype in 1839, the classical painter Paul Delaroche blurted out "From today, painting is dead!". ${ }^{2}$ Two decades later, in 1859, the poet Charles Baudelaire wrote, in a review of the Salon: "If photography is allowed to supplement art in some of its functions, it will soon supplant or corrupt it altogether, thanks to the stupidity of the multitude which is its natural ally".3

This conception of photography never fully died away: for a very long time, photography was exclusively considered as a mechanical recording medium, an instrument for objectively capturing reality. ${ }^{4}$

For these reasons, in the first organic Italian legislation on cultural heritage, Law No. 1089 of 1 June 1939,5 on the protection of "things of artistic or historical interest", there was no reference to photography, an artistic and expressive technique considered too far from the aesthetic and idealistic conception of "things of artistic or historical interest" underlying that legislation. In fact, Law 1089/1939 was interested only in cultural manifestations particularly significant for their aesthetic, historical, and (in practice) economic value. According to this elitist and conservative idea the Law, building on a static protectionist approach, was aimed at preserving mainly outstanding and rare masterpieces. ${ }^{6}$

\footnotetext{
2 See A. Scharf, Art and Photography, Penguin, Harmondsworth 1968; N. Rosenblum, A World History of Photography, Abbeville Press, New York 1984.

3 See A. Hertzmann, Can Computers Create Art?, "Arts" 2018(7), https://arxiv.org/pdf/1801.04486.pdf [accessed: 08.04.2019].

4 See E. Rizzo, La fotografia come documento del patrimonio, "Arte Ricerca", http://www.artericerca.com/Fotografia/La\%20fotografia\%20come\%20documento\%20del\%20patrimonio.html [accessed: 06.10.2018]; G. Clarke, The Photograph. A Visual and Cultural History, Oxford University Press, Oxford 1997, pp. 3-21.

5 Legge 1 giugno 1939, n. 1089 "Tutela delle cose di interesse artistico e storico" [Law No. 1089 of 1 June 1939 "Protection of things of artistic or historical interest"], Gazzetta Ufficiale No. 184, 8 August 1939.

6 Cf. N. Assini, G. Cordini, I beni culturali e paesaggistici: diritto interno, comunitario, comparato e internazionale, CEDAM, Padova 2006, p. 11.
} 
Even though the origin of photography and its importance as an instrument for documenting reality dates back to the mid-19th century, ${ }^{7}$ photography entered the sphere of recognized arts only by virtue of the interest shown by the avant-gardes of the early 20th century. This new status was only definitively secured by the establishment of the photography department of the Museum of Modern Art in New York in 1940, which determined the shift of photography from documents of reality $^{8}$ to works of art. $^{9}$ The crucial passage occurred in the 1970 s, thanks to the work of some enlightened artists who undermined the supposed documentary value of photographs, paving the way for their emergence as an artistic medium. ${ }^{10}$

Nevertheless, in the 1980s difficulties remained in terms of recognizing photographs as works of art from a legal perspective. In an important decision of the European Court of Justice (Ingrid Raab v. Hauptzollamt Berlin-Packhof) ${ }^{11}$ it was argued that under customs law all photographs should be classified under the commodities section of the Common Customs Tariff (CCT), ${ }^{12}$ in particular under the code for "images, engravings and photographs" in Chapter 49 CCT, and should therefore be subject to customs duties - even those realized by an artist and endowed with artistic value. The Court stated that (even artistic) photographs could neither be classified under the code for "original engravings, prints and lithographs", nor under the category of "artists' screen prints" (both exempt from customs duties),

7 In 1854 the Société française de photographie was created in France. In Italy, in 1892, a Photographic Office was founded within the Ministry of Education, with a public archive and a centre for the production of photographic materials, which later became the National Photographic Department. In 1924 the Istituto LUCE (L'Unione Cinematografica Educativa - The Educational Cinematic Union) was created, which acquired news archives and photographic funds and collections. In Geneva, Demole founded the Swiss Museum of Documentary Photographs in 1900. In the same year, in England Benjamin Stone formed a collection of photographic prints in the British Museum.

8 See G. Clarke, op. cit., pp. 161-190.

9 See ibidem, pp. 191-214.

10 See e.g. M. Paderni, Laboratorio Italia. La fotografia nell'arte contemporanea, Johan\&Levi, Milano 2009, pp. 11-15; C. Cotton, La fotografia come arte contemporanea, Einaudi, Torino 2010; B. Blanchard, Art contemporain, le paradoxe de la photographie, L'Harmattan, Paris 2014; D. Bate, Art Photography, Tate Publishing, London 2015. In the 1960s and 1970s, artists who worked in performing art, body art, and site-specific artworks used photography as documentation: photography soon became an object of collection and exhibition, as in the cases of Sophie Calle, Yves Klein, Joseph Beuys, and Marina Abramović. Between the end of the 1970s and the 1980s, photography went beyond such a purely documentary dimension, in which photography and video were used to keep alive the memory of happenings and live performances, and became an instrument of narration of social behaviours, interactions, and stories of the contemporary society.

11 Cf. Case C-1/89, Ingrid Raab v. Hauptzollamt Berlin-Packhof, ECR, 1989, 4423. For a critical appraisal, cf. A. Donati, La definizione giuridica di opera d'arte e le nuove forme di espressione artistica contemporanea, "Rivista del Consiglio" 2017-2018, pp. 121-127, and eadem, Rilevanza giuridica dell'archivio d'artista, in: Impresa Cultura. Creatività, partecipazione, competitività. XII Rapporto annuale Federculture, Gangemi, Roma 2016, pp. 185-195.

12 Council Regulation (EEC) No. 2658/87 of 23 July 1987 on the tariff and statistical nomenclature and on the Common Customs Tariff, OJ L 256, 7.09.1987. 


\section{GENERAL ARTICLES}

Eliana Romanelli

as Chapter 99 CCT refers only to works which are made by hand of the artist, thus excluding works which, like photographs, are realized, even in their original form, using technical equipment. The Court added that while the objects referred to in Chapter 99 CCT are almost always works of art, the same could not be said for photographs, most of which are not artistic. This decision manifestly prejudiced the export of photographs, contrary to the intention of European lawmakers to ensure privileged treatment of all original works of art. ${ }^{13}$

\section{The Genesis of the Consideration of Photographs as Cultural Property within Italian Law}

Within the Italian legal framework, photography has often been the object of a debate, in both scholarly works and the case law, over its nature as an original and creative work protected under Article 2 of intellectual property law (Law No. 633 of 22 April 1941) ${ }^{14}$ when endowed with artistic value or possessing creative features. ${ }^{15}$ The attention given to photography is mainly linked to the recognition of author's moral rights and copyright. Nevertheless, the Italian widespread cultural heritage regulatory framework includes photographs as well, ${ }^{16}$ even if this specific take on photography as cultural property is very recent.

The current relevance of the issue is demonstrated, for instance, by the inclusion, amongst the 2016/2017 Ministry for Cultural Property and Activities (MiBACT) acquisitions, of a photographic portrait of Puccini, Mascagni, and Franchetti, dated 1893, which was the object of a compulsory purchase in 2016, prompted by the Superintendency - the administrative local organ of the MiBACT - of Turin, pursuant to Article 70 of the Cultural Heritage Code, with the aim of preventing the export of an item considered of great cultural relevance for the national heritage. ${ }^{17}$

13 See A. Puttemans, B. Demarsin, Les aspects juridiques de l'art contemporain, Larcier, Bruxelles 2013; A. Donati, "Art as Idea as Idea". Diritto e creazione artistica contemporanea, "Quaderni del dottorato fiorentino in Scienze giuridiche" 2017; eadem, La definizione..., pp. 121 and 125-126.

14 Legge 22 aprile 1941, n. 633 "Protezione del diritto d'autore e di altri diritti connessi al suo esercizio" [Law No. 633 of 22 April 1941 "Protection of copyright and neighbouring rights"], Gazzetta Ufficiale No. 166, 16 July 1941 (as amended up to Legislative Decree No. 154 of 26 May 1997).

15 See e.g. G. Arciero, La fotografia nel diritto d'autore. I codici della fotografia, Nuova Arnica, Roma 1985; S. Dell'Arte, Fotografia e diritto, UTET, Torino 2014; E. Trigari, Il diritto nella fotografia - Diritto d'autore, privacy e altri diritti, Aracne, Roma 2013; N. Rositani, I. Zannier, La fotografia. Dall'immagine all'illecito nel diritto d'autore, Skira, Milano 2005; R. Mongillo, Proprietà intellettuale ed opera fotografica, "Quaderni della rivista di diritto dell'impresa" 2018.

16 Cf. S. Dell'Arte, op. cit., p. 300; F. Menapace, Una storia per immagini: la fotografia come bene culturale, Provincia Autonoma di Trento - Servizio beni culturali, Trento 1996. 
To further enhance the value of photography as part of Italian cultural heritage, on 4 May 2018 the Ministry published a strategic plan for the development of photography in Italy, aimed at creating a permanent structure for the conservation of Italy's photographic heritage and the enhancement of photography as a relevant part of contemporary art and national creativity. ${ }^{18}$

This strong interest in photography arose in Italy after the Second World War, animated by a new awareness of the need to safeguard photographic objects not only as a documentary source, but also as items having cultural value in themselves. The emergence of new artistic forms and the identification of further categories of cultural property pushed some Italian scholars to highlight the limits of Law 1089/1939. On the one hand, its mainly "idealistic" and aesthetic approach allowed for the inclusion only of a part of culturally relevant objects and, on the other, it overlooked new and influential theoretical approaches that were gaining recognition by the middle 1960 s. ${ }^{19}$

A different vision of the national richness in objects of art and antiquity was emerging, which privileged a more historical-anthropological approach, i.e. one "able to emphasize the importance that the thing has in the history of evolution of the civilization of which it is a document, memory of the time in which it arose". ${ }^{20}$ This perspective also informed the works of the Commissione Franceschini. ${ }^{21} \mathrm{Al}-$ beit only marginally addressing the issue of photographs in its final Declarations photographs were included in the proposed definition of "cultural property of bibliographical interest" in Declaration LIV, provided that they presented "special relevance" in terms of "antiquity, paleographical interest, historical interest, literary, scientific, or artistic interest" - the Commission effected a change in the understanding of protection and enhancement policies for cultural heritage ${ }^{22}$ which would eventually affect the legal status of photographs as cultural property.

18 Cf. Ministero per i beni e le attività culturali e per il turismo, Piano strategico di sviluppo della fotografia in Italia, 2018-2022, http://www.beniculturali.it/mibac/multimedia/MiBAC/documents/1525355716796_ Piano_Strategico_di_Sviluppo_della_Fotografia_in_Italia-1.pdf [accessed: 05.10.2018].

19 Cf.M.P.Chiti, La nuova nozione di “beni culturali” nel d.lg. 112/1998: prime note esegetiche, "Aedon" 1998(1), http://www.aedon.mulino.it/ [accessed: 06.10.2018].

20 Cf. G. Volpe, Manuale di diritto dei beni culturali: storia e attualità, CEDAM, Padova 2013, p. 112.

21 Commissione d'indagine per la tutela e la valorizzazione del patrimonio storico, archeologico, artistico e del paesaggio, established under Law No. 310 of 26 April 1964, in order to reach a comprehensive rationalization of the Italian legislation on "historic, archaeological, artistic and natural heritage". See Per la salvezza dei beni culturali in Italia. Atti e documenti della Commissione d'indagine per la tutela e la valorizzazione del patrimonio storico, archeologico, artistico e del paesaggio, Colombo, Roma 1967; W. Cortese, I beni culturali e ambientali. Profili normativi, CEDAM, Padova 1999, p. 40.

22 Cf. V. Cerulli Irelli, I beni culturali nell'ordinamento italiano vigente, in: M.P. Chiti (ed.), Beni culturali e Comunità Europea, Giuffrè, Milano 1994, p. 2; G. Severini, Disposizioni generali, in: M.A. Sandulli (ed.), Codice dei beni culturali e del paesaggio, Giuffrè, Milano 2012, p. 23. See e.g. Consiglio di Stato, s. VI, 17 October 2003, No. 6344, which underlined that cultural property can be protected also for historical reasons, because it is fundamental to gain knowledge about the past and to the progress of science. 


\title{
GENERAL ARTICLES
}

\author{
Eliana Romanelli
}

Afterwards, the first legal definition of "cultural property", introduced in Article 148(a) of the Legislative Decree No. 112 of 31 March $1998,{ }^{23}$ did not make any explicit reference to photography, even if previous legislation (Decree of the President of the Republic No. 805 of 3 December 1975, Article 29) ${ }^{24}$ had introduced a national institute for graphic arts (currently the Istituto Centrale per la Grafica), charged with the "safeguarding, cataloguing and the dissemination of objects concerning graphic and photographic production".

It was only with the drafting of the Unified Text of cultural property and landscape assets legislation (Legislative Decree No. 490 of 29 October 1999, henceforth "1999 UT" $)^{25}$ that photography came to be legally qualified as cultural property, subject to the related provisions of protection, conservation, and enhancement. ${ }^{26}$

Article 2(2)(e) 1999 UT included amongst cultural properties also "photographs with relative negatives and matrixes, having characters of rarity and artistic or historic value", the latter features being needed to identify the qualified cultural interest needed to subject photographs to the legal protection regime. Article 3(1)(d) also included amongst cultural property subject only to specific provisions - namely, for the purposes of limiting their exportation - such photographs which had been produced more than 25 years before the intended export, whose transfer abroad was prohibited when deemed harmful to the "national historic and cultural heritage" according to Article 65(1).

The 1999 UT also provided for implementation of the European Regulation on the export of cultural goods outside the borders of the European Community (at the time, Council Regulation EEC 3911/92, ${ }^{27}$ now Council Regulation

23 Decreto Legislativo 31 marzo 1998, n. 112 "Conferimento di funzioni e compiti amministrativi dello Stato alle regioni ed agli enti locali, in attuazione del capo I della Legge 15 marzo 1997, n. 59" [Legislative Decree No. 112 of 31 March 1998 "Conferral of functions and administrative tasks of the State to the Regions and local bodies, in implementation of chapter I of Law No. 59 of 15 March 1997"], Gazzetta Ufficiale No. 92, 21 April 1998.

24 Decreto del Presidente della Repubblica 3 dicembre 1975, n. 805 "Organizzazione del Ministero per i beni culturali e ambientali" [Decree of the President of the Republic No. 805 of 3 December 1975 "Organization of the Ministry of Cultural Property and Activities"], Gazzetta Ufficiale No. 23, 27 January 1976.

25 Decreto Legislativo 29 ottobre 1999, n. 490 "Testo unico delle disposizioni legislative in materia di beni culturali e ambientali a norma dell'articolo 1 della legge 8 ottobre 1997, n. 352" [Legislative Decree No. 490 of 29 October 1999 "Unified Text of cultural and landscape assets legislation, pursuant to Article 1 of the Law No. 352 of 8 October 1997"], Gazzetta Ufficiale No. 302, 27 December 1999. The 1999 UT was expressly repealed and replaced by Legislative Decree No. 42 of 22 January 2004, which introduced the Cultural Heritage Code, the current legislation in force.

26 Cf. E. Rizzo, La fotografia come bene culturale, "Arte Ricerca", http://www.artericerca.com/Fotografia/ La\%20fotografia\%20come\%20Bene\%20culturale.html [accessed: 06.10.2018]; G. Pitruzzella, La nozione di bene culturale (artt. 1, 2 , 3 e 4 d.lg. 490/1999), "Aedon" 2000(1), http://www.aedon.mulino.it/ [accessed: 06.10.2018]; M. Cammelli (ed.), La nuova disciplina dei beni culturali e ambientali. Commento al Testo Unico approvato con il d.lg. 29 ottobre 1999, n. 490, II Mulino, Bologna 2000.

27 Council Regulation (EEC) No. 3911/92 of 9 December 1992 on the export of cultural goods, OJ L 395, 31.12.1992. The Regulation on the export of cultural goods outside the territory of the European Commu- 
EC 116/200928). Article 72 and Annex A, implementing the Regulation and its Annex with their age and financial value thresholds, provided that photographs and related negatives older than 50 years and which did not belong to the photographer, the value of which was equal or higher than $27,067,800$ ITL (15,000 ECU), could be exported outside the European Community only by obtaining an export licence.

\section{The Legal Status of Photographs in the 2004 Cultural Heritage Code}

In 2004 , the Cultural Heritage Code $(\mathrm{CHC})^{29}$ was introduced by Legislative Decree No. 42 of 22 January 2004. The new law maintained the mixed system (i.e., cultural property subject to all effects and cultural property subject only to specific protection measures) of the 1999 UT, ${ }^{30}$ making some changes to the legal definitions and discipline.

On one hand, the broad definition of Article $2 \mathrm{CHC}$ allows to consider as "cultural property" (bene culturale) any object that, by or according to the law, has been identified as "testimony with a civilization value". On the other hand, Article $10 \mathrm{CHC}$ lists and defines cultural properties subject to all the rules established for the protection of the cultural heritage, while Article $11 \mathrm{CHC}$ sets out a number of other objects qualified as cultural properties only for purposes of the application of certain specific protection provisions and which are subject only to some specific obligations expressly stated in the Code. ${ }^{31}$ In particular, as stated below, besides photographs, Article 11 includes other peculiar typologies of objects with specific age thresholds, such as "samples of cinematographic works, audio-visual material or sequences of images in movement, the documentation of events, oral or verbal, produced by any means, more than twenty-five years ago" (Article 11.1.f); "means

nity established a standard prior authorization (export license) valid within the whole European Community as a requirement to export the goods listed in its Annex outside Community's borders.

28 Council Regulation (EC) No. 116/2009 of 18 December 2008 on the export of cultural goods (codified version), OJ L 39, 10.02.2009.

29 Decreto Legislativo 22 gennaio 2004, n. 42 "Codice dei beni culturali e del paesaggio" [Legislative Decree No. 42 of 22 January 2004 "Cultural Heritage Code"], Gazzetta Ufficiale No. 45, 24 February 2004. See e.g. R. Tamiozzo, Il Codice dei Beni Culturali e del Paesaggio, Giuffrè, Milano 2004; M. Cammelli, II Codice dei beni culturali e del paesaggio: dall'analisi all'applicazione, "Aedon" 2004(2), http://www.aedon.mulino.it/archivio/2004/2/cammelli.htm [accessed: 30.03.2019].

30 Cf. G. Severini, op. cit., p. 27; G. Volpe, op. cit., p. 126; G.L. Perdonò, L'uso illecito e le violazioni in materia di alienazione: riproposizione di vecchi schemi a fronte della rinuncia alle chances offerte dalle nuove frontiere della politica criminale, in: A. Manna, II Codice dei beni culturali e del paesaggio. Gli illeciti penali, Giuffrè, Milano 2005, p. 118.

31 Cf. N. Assini, G. Cordini, op. cit., pp. 67-68; G. Sciullo, I beni, in: C. Barbati, M. Cammelli, G. Sciullo (eds.), Diritto e gestione dei beni culturali, II Mulino, Bologna 2011, pp. 28-31; G. Morbidelli, Art. 11, in: M.A. Sandulli (ed.), Codice dei beni culturali e del paesaggio, Giuffré, Milano 2012, pp. 134-136. 


\section{GENERAL ARTICLES}

Eliana Romanelli

of transport which are more than seventy-five years old" (Article 11.1.g); "property and instruments of interest for the history of science and technology which are more than fifty years old" (Article 11.1.h).

Article 10(4)(e) CHC - the so-called "illustrative cultural property" list, ${ }^{32}$ which is not to be considered closed - also includes "photographs, with their relative negatives and matrixes, [...] of a rare and precious value", which may belong either to public or assimilated subjects ${ }^{33}$ and have an artistic and historical interest according to Article 10(1), or to private persons and have a qualified ("particularly important") such interest, whose cultural value is to be formally declared pursuant to Article 13 (cf. Article 10.3.a). Thus photography possessing the required features of rarity and cultural relevance (even if not, necessarily, those of originality, creativity, and artistic value required for protection under (talian copyright law) is subject to the Code provisions as "cultural property". ${ }^{34}$

In addition, Article 11(1) CHC maintains in the list of "cultural property subject only to specific effects" 35 also "photographs, with their relative negatives and matrixes, [...] produced by any means, more than twenty-five years ago" (letter f), subjecting them to the export rules set out in Article 65(3)(c). Article 11 also specifies that whenever a photograph meets the requirements of Article 10, unless and until the issuance of a negative verification of cultural interest (for publicly-owned and assimilated objects, according to Article 12), or following the issuance of a positive declaration (for privately-owned objects, according to Article 13), it will be subject to the full extent of the Code's protection provisions. ${ }^{36}$

Article 65(3)(c), in turn, states that the permanent export outside domestic borders of photographs, belonging to anyone and produced more than 25 years ago, is subject to a specific authorization (the certificate of free circulation ex Article 68 in the case of export within the European Union, and also the EU export

32 Cf. G. Boldon Zanetti, II nuovo diritto dei beni culturali, Cafoscarina, Venezia 2016, pp. 61-62; G. Sciullo, Patrimonio e beni, in: C. Barbati et al. (eds.), Diritto del patrimonio culturale, II Mulino, Bologna 2017.

33 Article 10 (1) CHC refers to cultural property belonging to public owners (State, Regions, other territorial public bodies and any other public body and institution) or to private non-profit associations, including ecclesiastical entities with an acknowledged legal status (the so-called assimilated subjects). For further details cf. N. Assini, G. Cordini, op. cit., p. 67; G. Sciullo, I beni, pp. 28-31, and A. Visconti, The Reform of Italian Law on Cultural Property Export and its Implications for the "Definitional Debate": Closing the Gap with the European Union Approach or Cosmetics? Some Systemic Considerations from a Criminal Law Perspective, "Santander Art and Culture Law Review" 2019, Vol. 5(2), pp. 159-186.

34 Cf.S. Dell'Arte, op. cit., p. 301.

35 See Corte Costituzionale, 28 March 2003, No. 94, together with the comments of S. Foà, La legittimità costituzionale della I. reg. Lazio sulla tutela e valorizzazione dei locali storici, "Giornale di diritto amministrativo" 2003(9), p. 907; of P. Carpentieri, Tutela e valorizzazione dei beni culturali, "Urbanistica e appalti" 2003(9), p. 1017; and of F.S. Marini, I "beni culturali" ed i "locali storici" del Lazio: una differenza storico-normativa, "Giurisprudenza costituzionale" 2003(2), pp. 775-778. For further details, see e.g. G. Sciullo, I beni, p. 30 and P. Carpentieri, op. cit., pp. 1017-1018.

36 Cf. D. Antonucci, Codice commentato dei beni culturali e del paesaggio, Esselibri, Napoli 2009, pp. 98-99. 
licence ex Article 74 in the case of export outside the Union's borders), to be granted by the competent public authorities. Like for any other cultural property, also in the case of photographs if the Superintendency refuses the certificate, it has the duty to start the proceeding to declare the object's cultural interest (Articles 68 and 69).

Insofar as concerns the general administrative discipline of circulation outside the domestic borders of cultural goods, ${ }^{37}$ the Code forbids any permanent export (Article 65.1) for publicly-owned (and assimilated) cultural property with an artistic and historical interest, for which no negative verification of culturality has taken place pursuant to Article 12 (verifica dell'interesse culturale) ${ }^{38}$ and which cannot be qualified as "contemporary works" (Articles 10, Paragraphs 1, 2, and 5, and 65.1), and for (usually) privately-owned cultural property with a particularly important artistic or historical interest for which a positive declaration of cultural relevance has been made pursuant to Article 13 (dichiarazione di interesse culturale); ${ }^{39}$ a declaration which, in turn, can only occur for objects which cannot be qualified as "contemporary works" according to the age threshold set out in Article 10(5) (cf. Articles 10.1, 10.3, and 65.2.b) or, as mentioned above, which are in any case below the specific age thresholds set for some particular typologies of objects (including photographs) in Article 11(1), letters f), g), and h). ${ }^{40}$

According to Article 65(3), for other (usually privately-owned) but not yet positively declared cultural property permanent export is actually possible, but it is subject to the aforementioned authorization granted by the competent public authorities.

37 Cf. A. Visconti, op. cit., pp. 172-173; G. Tempesta, La tutela dei beni culturali: aspetti di diritto italiano, di diritto canonico e dei trattati internazionali, in: T. Scovazzi, La restituzione dei beni culturali rimossi con particolare riguardo alla pratica italiana, Giuffrè, Milano 2014, pp. 275-276; M. Frigo, La circolazione internazionale dei beni culturali. Diritto internazionale, diritto comunitario e diritto interno, Giuffrè, Milano 2007, p. 70; N. Assini, G. Cordini, op. cit., pp. 152-153; R. Tamiozzo, La legislazione dei beni culturali e paesaggistici, Giuffrè, Milano 2014, pp. 279-282; M. Ainis, M. Fiorillo, L'ordinamento della cultura, Giuffrè, Milano 2015, pp. 245-254; G. Sciullo, Tutela, in: C. Barbati et al. (eds.), Diritto del patrimonio culturale, II Mulino, Bologna 2017.

38 Cf. A. Visconti, op. cit., pp. 168-169; G. Vesperini, Il silenzio nel regime dei beni culturali, "Aedon” 2006(2), http://www.aedon.mulino.it/archivio/2006/2/vesperini.htm [accessed: 16.04.2019]; A. Barletta, Art. 12, in: M.A. Sandulli (ed.), Codice dei beni culturali e del paesaggio, Giuffré, Milano 2012, pp. 137-141; G. Sciullo, La verifica dell'interesse culturale (art. 12), "Aedon" 2004(1), http://www.aedon.mulino.it/archivio/2004/1/ art12.htm [accessed: 16.04.2019]; A. Rende, R. Rolli, Lo status giuridico dei beni culturali. Individuazione, vincoli ed incentivi, "Giustizia amministrativa” 2006(3), pp. 487-498; G. Morbidelli, Art. 10, in: M.A. Sandulli (ed.), Codice dei beni culturali e del paesaggio, Giuffré, Milano 2012, pp. 128-129.

39 In this case, the competent authority has to communicate the start of the declaration procedure to the owner, possessor, or holder of the property and has to notify them of the positive declaration which ascertains the existence, in the thing in question, of the cultural relevance according to Articles $13-15 \mathrm{CHC}$. Cf. A. Visconti, op. cit., pp. 168-169; A. Rende, R. Rolli, op. cit., pp. 487-498; C. Zucchelli, Artt. 13-16, in: M.A. Sandulli (ed.), Codice dei beni culturali e del paesaggio, Giuffrè, Milano 2012, pp. 147-220; N. Assini, G. Cordini, op. cit., p. 69; G. Caruso, Dichiarazione dell'interesse: dalla verifica al ricorso, "Guida al Diritto" 2004(4).

40 See e.g. G. Volpe, op. cit., pp. 126-127; G. Sciullo, I beni, p. 30. 


\section{GENERAL ARTICLES}

Eliana Romanelli

Finally, the export of "contemporary works" (i.e. movable artworks of living authors or, prior to the 2017 reform, which were not produced more than 50 years prior to export) was already free under the original 2004 provisions: no export certificate was required, even if the exporter had a duty, under Article 65(4), to make a declaration and provide information to the export office (Articles 10.5, 11.1.d, and 65.4). ${ }^{41}$

Thus the legal status of photographs (as well as of negatives and matrixes) and their export discipline under Italian law between 2004 and 2017, according to a joint reading of Articles 10, 11, and $65 \mathrm{CHC}, 42$ can be summarized as follows: 1) Photographs in public ownership or assimilated, which did not fall within the scope of "contemporary works" as defined prior to 2017, were subject to all protection provisions, and their permanent export was prohibited, unless and until a negative verification of their cultural interest (rarity and value related to artistic or historical interest) was issued (Articles 10, Paragraphs 1, 4, and 5, and 65.2.a). 2) Photographs in the ownership of either public bodies or of private individuals or organizations (be the latter for profit or not), which were older than 25 years, ${ }^{43}$ and had never been declared of cultural interest, were subject, in case of export, to a check of their possible rarity and value, in relation to their artistic or historical interest (when in public ownership or assimilated), or to their "particularly relevant" artistic or historical interest (when in private ownership), and therefore to an obligation to be presented to the competent office for authorization in cases where permanent exportation was sought (Articles 10, Paragraphs 3.a and 4.e, 11.1.f, and 65.3.c). It must be underlined that if the Superintendency refuses the export permission, public authorities have the duty to start the proceeding to declare the cultural interest (Articles 68-69 CHC) and, if present, to positively declare it and, in this case, the Ministry or the Region may also decide for a compulsory purchase of the photograph within 90 days from the presentation of the artwork to the competent office (Article $70 \mathrm{CHC}$ ). ${ }^{44}$

3) Photographs in (usually) private ownership (but not only: see point 2, above), with features of rarity and value in relation to their particularly important artistic or historical interest, once however positively declared (and notified to the owner,

41 Cf. A. Visconti, op. cit., pp. 169 and 173; N. Assini, G. Cordini, op. cit., p. 153; G. Volpe, op. cit., p. 294; R. Tamiozzo, La legislazione dei beni culturali..., pp. 282 and 347.

42 Cf. A. Roccella, Manuale di legislazione dei beni culturali, Cacucci, Bari 2017, pp. 92-93; G. Boldon Zanetti, op. cit., pp. 65-66; S. Dell'Arte, op. cit., p. 307.

43 In the practice of the photography's market, the time of production of the photography is conventionally indicated as the time when the photography is printed.

44 See G. Magri, La circolazione dei beni culturali nel diritto europeo: limiti e obblighi di restituzione, Edizioni Scientifiche Italiane, Napoli 2011, pp. 108-109; R. Tamiozzo, La legislazione dei beni culturali..., pp. 350-353; G. Volpe, op. cit., pp. 274-276 and 295-296; M. Frigo, op. cit., p. 69; G. Sciullo, Le funzioni, in: C. Barbati, M. Cammelli, G. Sciullo (eds.), Diritto e gestione dei beni culturali, II Mulino, Bologna 2011, pp. 93-94. 
possessor, or holder), were subject to all protection provisions, including the prohibition of permanent export (Articles 10, Paragraphs 3.a and 4.e, and 65.1).

Consequently, export was freely permitted for photographs, belonging to anyone, produced less than 25 years prior to the intended exit outside national borders. ${ }^{45}$

From a criminal law perspective (Article $174 \mathrm{CHC}$ ) ${ }^{46}$ - given the strict intertwining of administrative and penal provisions, aimed at protecting cultural heritage and built in order to ensure compliance with the administrative provisions regulating the export of cultural property ${ }^{47}$ - an offence was committed if a photograph falling under situations 1) or 3) was permanently exported (or was not brought back after the expiry of the period for which a temporary export licence was granted), as well as whenever the export occurred in breach of the provisions of Articles 11(1)(f) and 65(3)(c), without having requested or obtained the certificate of free circulation and/or the export licence, even if the photograph had not yet been declared cultural property. This also means that in the case of photographs falling under point 2), it was up to the penal judge to autonomously assess the presence in the object of the cultural interest required under the law. ${ }^{48} \mathrm{It}$ is interesting to highlight that the criminal offence set out in Article $174 \mathrm{CHC}$ does not actually require a prior declaration of the cultural interest of the illegally exported object; the presentation to the export office of a request for an export certificate is one of those circumstances in which public authorities have the opportunity to identify and intercept goods with cultural interest which could be submitted to the Code's provisions. ${ }^{49}$

The reason why photographs produced more than 25 years ago were subject to specific restrictions was related to the peculiar nature of these particular forms

45 Cf. A. Donati, Nuovi criteri per il rilascio dell'attestato di libera circolazione, paper presented during the conference La circolazione dei beni culturali. I primi due anni della riforma, Milano, 9 April 2018; S. Dell'Arte, op. cit., p. 307.

46 See e.g. V. Manes, La tutela penale, in: C. Barbati, M. Cammelli, G. Sciullo (eds.), Diritto e gestione dei beni culturali, II Mulino, Bologna 2011, pp. 299-300; idem, La circolazione illecita dei beni artistici e archeologici. Risposte penali ed extrapenali a confronto, in: Circolazione dei beni culturali mobili e tutela penale: un'analisi di diritto interno, comparato e internazionale, Giuffrè, Milano 2015, pp. 94-96; G. Volpe, op. cit., pp. 355-357; A. Massaro, Illecita esportazione di cose di interesse artistico: la nozione sostanziale di bene culturale e le modifiche introdotte dalla legge n. 124 del 2017, "Diritto penale contemporaneo" 2018(5), pp. 116-121; M. Trapani, Riflessioni a margine del sistema sanzionatorio previsto dal c.d. codice dei beni culturali, in: E. Battelli et al., Patrimonio culturale. Profili giuridici e tecniche di tutela, RomaTrE-Press, Roma 2017, pp. 244-245.

47 Fur further details, see A. Visconti, op. cit., pp. 171 and 173; V. Manes, op. cit., p. 292; S. Manacorda, La circolazione illecita dei beni culturali nella prospettiva penalistica: problemi e prospettive di riforma, in: Circolazione dei beni culturali mobili e tutela penale: un'analisi di diritto interno, comparato e internazionale, Giuffrè, Milano 2015, pp. 12-13. Cf. also Corte di Cassazione, s. III pen., 20 July 2017, No. 39517.

48 Cf. A. Visconti, op. cit., p. 173.

49 Cf. ibidem; M.A. Sandulli (ed.), Codice dei beni culturali e del paesaggio, Giuffrè, Milano 2012, pp. 1266-1267. 


\section{GENERAL ARTICLES}

Eliana Romanelli

of cultural property, ${ }^{50}$ and lies in the fact that they are considered objects which, when meeting the required standards of cultural interest, must be safeguarded as elements of documentation of the history and civilization of the nation, not as valuable specific artistic items. ${ }^{51}$

The relevant question, thus, is to check whether, and if in the affirmative how, the recent reform of Italian export rules has impacted the specific discipline for photographs summarized above, or whether instead, the already particular export regime for these items has remained unchanged after 2017, and if the latter, what could be the consequences of this enduring exception.

\section{The 2017 Reform of the Cultural Heritage Code and Its Effects on the Export of Photographs}

Starting from August 2017, the above-analysed regime regulating the circulation of cultural property in Italy has been amended by Law No. 124 of 4 August 2017,52 Article 1, Paragraphs 175-176, which modified the Code in order to simplify and enhance the Italian art market's efficiency and competitiveness. ${ }^{53}$

Under the new (standard or "general") regime (Article 10.5 CHC, new text), the relevant age threshold to be considered in order to qualify a certain thing as culturally relevant has been extended from 50 to 70 years from the creation of the artwork, so that objects which are the work of living authors, or which are the work of deceased authors but were produced less than 70 years ago - "contemporary works" - need no export certificate in case of permanent export outside domestic borders. ${ }^{54}$

The reform also added the new letter d-bis) to Article 10(3), introducing a new category of exceptionally relevant cultural property, which, to be considered as such, needs to have been produced more than 50 years ago and to be the work

50 See A. Roccella, op. cit., pp. 92-93.

51 Cf. G. Boldon Zanetti, op. cit., pp. 65-66.

52 Legge 4 agosto 2017, n. 124 "Legge annuale per il mercato e la concorrenza" [Law No. 124 of 4 August 2017 "Annual trade and antitrust law"], Gazzetta Ufficiale No. 189, 14 October 2017.

53 Cf. e.g. G. Calabi, V. Favero, Progetto Apollo. Verso una riforma del mercato dell'arte, "Wannenes Art Magazine" 2017, Vol. 7(1), https://wannenesgroup.com/magazine/progetto-apollo-verso-una-riforma-del-mercato-dellarte/ [accessed: 28.09.2018]; H. Marsala, II Ddl concorrenza è legge. Cosa cambia per arte e beni culturali, "Artribune", 3 August 2017, http://www.artribune.com/arti-visive/archeologia-arte-antica/2017/08/ politica-mercato-ddl-concorrenza-e-legge-cosa-cambiaper-arte-beni-culturali-polemiche/ [accessed: 28.09.2018]; G. Calabi, Italy, in: P. Valentin (ed.), Art Law 2018, Law Business Research Ltd., London 2018, https://www.artatlaw.com/wp-content/uploads/2018/06/AL2018Engand-Wales.pdf [accessed: 12.10.2018]; A. Pirri Valentini, Il patrimonio culturale tra separazione dei poteri e controllo giurisdizionale: il caso dell'esportazione di opere d'arte, presentation at the AIPDA annual symposium 2018, http://www.diritto-amministrativo.org/index.php?page=42 [accessed: 06.04.2019]; A. Visconti, op. cit., pp. 174-178.

54 See A. Visconti, op. cit., pp. 174-175 and 177-178. 
of a non-living author (Article 10.5, new text), as well as possesses an "artistic, historical, archaeological or ethno-anthropological interest which is exceptional for the integrity and completeness of the cultural heritage of the nation". For this category of artworks, the Ministry shall be entitled to ascertain whether the object has such an exceptional interest and, in affirmative cases, within 60 days from the start of the proceeding the competent public authorities shall declare the artwork "cultural property" and officially notify it as such to the owner, thus subjecting it to all the protection provisions of the Code. ${ }^{55}$ According to Article 65(4-bis), the competent export office, which considers that an artwork should be included among the cultural property referred to in Article 10(3)(d-bis), has to initiate the declaration proceeding pursuant to Articles 13-15 CHC.

Finally, the 2017 reform introduced a (unprecedented for Italy) financial value threshold of $€ 13,500$, under which cultural objects which are the work of a deceased author and which were produced more than 70 years ago can, nonetheless, be freely exported on the basis of the owner's unilateral declaration presented to the competent export office of the local Ministry's deputy authority, i.e. the Superintendency (Article 65.4.b). The application of the financial value threshold (which, however, does not apply to archaeological remains, parts of dismembered monuments, incunabula and manuscripts, and archives) was declared to be suspended until 31 December 2019, the date within which the missing Ministerial Decrees (see below) shall be enacted. ${ }^{56}$

However, the 2017 reform is not yet completed since it has to be implemented through further Ministerial Decrees ${ }^{57}$ which, at present, have only partially been enacted.

This new complex and innovative scenario resulting from the 2017 reform, with its addition to existing age thresholds and the new financial value threshold, has raised the question of whether the new legislation has affected the regulation of the export of photographs as cultural property, with its specific parameters and discipline.

\footnotetext{
55 See ibidem, pp. 174-175.

56 See Decreto Ministeriale 9 luglio 2018, n. 305 "Condizioni, modalità e procedure per la circolazione internazionale di beni culturali. Decreto integrativo" [Ministerial Decree No. 305 of 9 July 2018 "Conditions, methods and procedures for the international circulation of cultural property. Supplementary decree"]. Cf. A. Visconti, op. cit. pp. 174-175, note 75.

57 Decreto Ministeriale 6 dicembre 2017, n. 537 "Indirizzi di carattere generale per la valutazione del rilascio o del rifiuto dell'attestato di libera circolazione da parte degli uffici esportazione delle cose di interesse artistico, storico, archeologico, etnoantropologico" [Ministerial Decree No. 537 of 6 December 2017 "General directions for issuing or refusing a certificate of free circulation by the Export Offices for objects of artistic, historical, archaeological, ethno-anthropological value"], implementing the reform, has provided for a rationalization and specification of the criteria (the previous criteria dated back to 1974) according to which export offices may deny the required export certificate by declaring a cultural interest of the object. For further details, see A. Visconti, op. cit., p. 177.
} 


\section{GENERAL ARTICLES}

Eliana Romanelli

The first question is whether the raising of the age threshold of contemporary art, as well as the new specific regime for objects older than 50 years but no older than 70, set in Articles 10(3)(d-bis) and 65(4-bis), have directly affected photography.

The answer appears negative. Whenever a photograph was produced more than 25 years ago, it can be permanently exported only by obtaining a certificate of free circulation - even in cases where, it being in public ownership (or assimilated) but no older than 70 years (instead of the previous 50), its cultural value is not presumed until a negative verification. The specific lower age threshold provided for photographs was, in fact, left untouched by the reform ${ }^{58}$ and is, indeed, lex specialis, making an exception to the general provisions of the $\mathrm{CHC}$. Nevertheless, the assessment of cultural interest in photographs remains linked to the parameters set in the general guidelines recently modified by Ministerial Decree 537/2017. ${ }^{59}$

A different question refers to the impact on photography of the single monetary value threshold introduced in 2017, below which, as observed, the permanent export of objects with cultural relevance (made more than 70 years ago by artists that are no longer alive) does not require a certificate of free circulation, but only a declaration to the competent office. ${ }^{60}$ The financial threshold is expressly declared (Article 65.4.b, and Annex A, letter B, n. 1) to be not applicable to some categories - i.e. archaeological remains, incunabula, manuscripts, archives - for which an authorization is always required (provided they are not already declared, and thus forbidden from permanent export), regardless of their economic value. This list does not include photographs and, therefore, the value threshold might at first glance appear applicable to them as well.

However, the application of the value threshold is strictly limited to the cases indicated in Article 65(3)(a), which applies only to objects created more than 70 years ago and, as such, potentially subject to the Code's protection provisions. It could not apply to the export of photographs, for which the rules set by Article 65(3)(c) constitute lex specialis, providing for a different and specific age threshold, to which no value threshold was expressly added. ${ }^{61}$

Similarly, the Code's rules for export outside the EU territory have not been affected by the reform. ${ }^{62}$ This means that for extra-EU export of photographs

58 See also Ministero per i beni e le attività culturali e per il turismo, op. cit., pp. 22-23.

59 Cf. A. Visconti, op. cit., p. 177.

60 See F.E. Salamone, Circolazione internazionale delle opere d'arte ed introduzione delle "soglie di valore": un'occasione da non sprecare, "News-Art", 19 February 2018, http://news-art.it/news/circolazione-internazionale-delle-opere-d-arte-ed-introduzi.htm [accessed: 28.09.2018].

61 See Ministero per i beni e le attività culturali e per il turismo, op. cit., pp. 22-23.

62 Cf. A. Visconti, op. cit., pp. 175 and 179-180. See also Circolare Ministeriale 12 luglio 2018, n. 31 [Ministerial Circular No. 31 of 12 July 2018]. 
older than 50 years, not belonging to the author and whose value is higher than $€ 13,979.50$, an export licence is always required pursuant to Article $74 \mathrm{CHC} .{ }^{63}$

It must be noted that there is a great discrepancy between this financial value threshold, set in the Annex to the Code, and the one required by Council Regulation EC $116 / 2009$ for the extra-EU export of photographs ( $€ 15,000)$.

This difference might be related to an incorrect interpretation of the possibility, accorded to Member States by Article 2 of the Regulation, to define further categories of cultural property subject to national law, in addition to the cultural properties listed in Annex I of the Regulation. Photographs fall within the typologies of "national treasures" which are "cultural goods within the meaning" of the Regulation. They can, therefore, be subject to stricter limitations on export according to national law (Articles 1 and 2.2 of the Regulation), but the regime of their EU export licence (when admissible according to national law) remains ruled by the Regulation, a self-executing primary EU law. This divergence could more likely be explained by examining the history of Annex A of the Code. The Annex was already present in the 1999 UT, where the monetary thresholds set in Regulation EEC 3911/92, and expressed in the notional currency ECU, were converted to the Italian currency $(27,067,800$ ITL). The current value threshold of $€ 13,979.50$ is the exact equivalent in Euro of the 27,067,800 ITL of the 1999 UT, as converted by the lawmakers of 2004 Code according to the official exchange rate of 31 December 1998. This incorrect transposition was never amended afterwards, not even after the codification of Regulation EC 116/2009, with the value thresholds expressed in Euro ( $€ 15,000$ for photographs). Given the lack of critical consideration by experts and scholars on this point, the problem of the correct coordination between European and national law remains unresolved. It seems, however, more in line with the basic principles of EU primary law, as well as with Article 117 of the Italian Constitution, ${ }^{64}$ to interpret the Code provisions as being in compliance with the Regulation, a prevalent self-executing European source, so that conflicting national rules should not be applied. ${ }^{65}$

Moreover, it must be noted that there is a great difference between the restrictions on the export of photographs in Italy and the rules provided in other European countries. For instance, according to the German Cultural Goods Protection Act (Kulturgüterschutzgesetz of August 2016), photographs that are

63 See R. Leonardi, Esportazione dal territorio dell'Unione europea, in: M.A. Sandulli (ed.), Codice dei beni culturali e del paesaggio, Giuffrè, Milano 2012, pp. 639-649; M. Frigo, op. cit., p. 52.

64 Costituzione della Repubblica Italiana [Constitution of the Italian Republic], Gazzetta Ufficiale No. 298, 27 December 1947.

65 Cf. F. Lafarge, L'esportazione dei beni culturali dal territorio dell'Unione europea nel Testo Unico dei beni culturali, in: M. Cammelli (ed.), La nuova disciplina dei beni culturali e ambientali. Commento al Testo Unico approvato con il d.Ig. 29 ottobre 1999, n. 490, II Mulino, Bologna 2000, p. 219; P. Otranto, Commento agli artt. 73 e 74, in: A.M. Angiuli, V. Caputi Jambrenghi, Commentario al Codice dei beni culturali e del paesaggio, Giappichelli, Torino 2004, p. 212; F. Lemme, La tutela internazionale dei beni culturali e ambientali, in: N. Assini, P. Francalacci, Manuale dei beni culturali, CEDAM, Padova 2000, p. 16. 


\section{GENERAL ARTICLES}

Eliana Romanelli

older than 75 years and have an economic value of $€ 50,000$ need a certificate of free circulation in order to circulate within the EU borders, while for the export to third countries of photographs that are older than 50 years and worth more than $€ 15,000$ an export licence must be issued. In Spain, according to Law 16/1985 on the Spanish Historical Heritage (Ley del Patrimonio Histórico Español), an export authorization is needed for photographs that are between 50 and 100 years old, provided that their value exceeds $€ 15,000$. In France, the French Heritage Code (Code du Patrimoine, modified in 2015), states that photographs that are over 50 years old and worth more than $€ 50,000$ can be exported only with an export certification. In the United Kingdom, photographs with a value over $£ 12,305$ and which are more than 50 years old and do not belong to their originators are included in the EU categories for export outside the European borders, while photographic positives or negatives or any assemblage of such photographs, manufactured or produced more than 50 years before the date of exportation, and the value of which is less than $£ 10,000$, may be exported from the United Kingdom to any destination requiring an Open General Export Licence for the export to another EU State. ${ }^{66}$

Finally, it must be observed that under the Code photographs can also be considered as universitas of objects collected in an organic unit, thus falling within the definition of collections or archives. ${ }^{67}$

Collections are protected not only when, as originating in public institutions, they are considered cultural property ex lege according to Article 10(2), but also when, belonging to anyone, "through tradition, renown and particular environmental characteristics" they possess, as a whole, an "exceptional" artistic or historical interest (Article 10.3.e) and have consequently been subjected to an administrative declaration.

Archives - as movable collections of items and, according to the definition set in Article 101(1)(c) CHC, as permanent "institutions and places of culture" where "original documents of historical interest" are collected, inventoried, and preserved for purposes of study and research - are also considered as cultural property ex lege when they belong to public (or assimilated) owners, but are also "cultural property" when they belong to private owners and have been administratively declared as having a "particularly important historical interest" (Article 10.3.b). ${ }^{68}$

66 See International Bar Association, Art Law: Restrictions on the Export of Cultural Property and Artwork, November 2017, https://www.ibanet.org/Document/Default.aspx?DocumentUid=cba9a842-d0b8-4e 73-952a-a00406416d5d [accessed: 12.10.2018]; P. Valentin (ed.), Art Law 2018, Law Business Research Ltd., London 2018, https://www.artatlaw.com/wp-content/uploads/2018/06/AL2018Engand-Wales.pdf [accessed: 12.10.2018].

67 Cf. R. Tamiozzo, La legislazione dei beni culturali..., pp. 82-83.

68 See also A. Catelani, La tutela dei beni culturali audiovisivi da parte dello Stato italiano, "Rassegna parlamentare" 2007(4), pp. 837-856; E. Lodolini, Legislazione sugli archivi. Storia, normativa, prassi, organizzazione dell'amministrazione archivistica, Vols. I-II, Patron, Bologna 1998-2004. 
Public or declared archives and collections are forbidden from permanent export according to Article 65(1). For archives not yet declared of cultural interest, the rules are set out in Article 65(3)(b): permanent export outside domestic borders of archives belonging to private persons and possessing a particularly important historical interest is subject to a specific authorization.

The 2017 reform expressly excluded from the application of the newly introduced financial value threshold, amongst other things, the archives (Annex A, letter B, n. 1, §12, as recalled by Article 65.3.a), so that permission for their export will always be required regardless of their economic value. Thus, the export of a photographic archive without the required certificate of free circulation and/or export licence constitutes a criminal offence according to Article $174 \mathrm{CHC}$.

\section{Conclusions}

There is no doubt that the invention of photography has been one of the most important moments in recent history, becoming an instrument of memory, expression, and understanding and assuming an ever-increasing relevance as part of the national cultural heritage. The growing interest in photographs manifested in recent decades by collectors, museums and cultural institutions, temporary exhibitions, and art fairs has motivated the MiBACT to adopt strategic measures to protect and enhance the "photographic heritage" and the Central Institute for Catalogue and Documentation, with the support of Camera (Italian Centre for Photography) and the General Directorate for Contemporary Art and Architecture and Urban Suburbs, to start a new project, the Census of collections and photographic archives, which aims to strengthen the systematic knowledge of this important part of cultural heritage in order to set policies for its protection and valorization. ${ }^{69}$

All these initiatives have led to a formidable increase in the size and quotations of the photography market. ${ }^{70}$ In particular, there is a growing interest by collectors in photography, as demonstrated by the development of specialized art fairs devoted to photography (i.e. Mia Photo Fair in Italy; Paris Photo in France; Photo Basel in Swiss; Photo London in UK) and by the total turnover (around US\$50 million) recorded in 2017 by international auctions. ${ }^{71}$

\footnotetext{
69 See the website http://www.censimento.fotografia.italia.it/ [accessed: 25.04.2019].

70 Cf. Photography Market Report 2017, elaborated by ArtTactic, https://arttactic.com/product/photography-market-2nd-half-2017/ [accessed: 06.10.2018].

71 According to The Art Market 2017, elaborated by Art Basel \& UBS, $9 \%$ of the market value was generated by photography and the average prices of the artworks were around US\$15 million. See C. McAndrew, The Art Market 2017, Art Basel \& UBS, 2017, https://d33ipftjgrd91.cloudfront.net/asset/cms/Art_Basel_and_UBS_The_Art_Market_2017.pdf [accessed: 03.04.2019]. See also A. Crippa, Mercato e fotografia. Tempo di bilanci, "Artribune", 13 July 2018, https://www.artribune.com/professioni-e-professionisti/ mercato/2018/07/fotografia-aste/ [accessed: 02.04.2019]; and N. Maggi, Report Mercato Fotografia: 2018 anno record per l'Italia, "Collezione da Tiffany", 27 March 2019, https://www.collezionedatiffany.com/ report-mercato-fotografia-2018-anno-record-per-litalia/ [accessed: 09.04.2019].
} 


\title{
GENERAL ARTICLES
}

\author{
Eliana Romanelli
}

Given this scenario, the most relevant data is linked to the choice of the auction market, also in Italy, to focus on researching vintage photographs or photographs created by historicized and internationally recognized authors. ${ }^{72}$

In view of the structuring of the photography system, in order to be able to really acknowledge and support its key role as a core component of national cultural heritage and, at the same time, as an essential element of contemporary languages, a more organic reform of the Italian cultural heritage legal framework should probably have foreseen some changes also in the field of the export of photographs. A regulatory convergence towards the standards of the (new) "general" export regime for cultural property would also have been more compliant with the basic principles of rationality and uniformity of rules applicable to items with like features.

Moreover, the reform has not resolved the problem of so-called "forum shopping" which, especially in the field of photography, adds further complexity to a special legislation often unknown to and/or not correctly applied by market operators. The absence of a unified central authority, the discretion that permeates the application of the export rules, and the lack of consistency between practices followed by different Superintendencies causes uncertainty in the interpretation of the law across the country. ${ }^{73}$

In this scenario, the 2017 reform should have ensured greater certainty in the field of cultural property's export, better balancing of all the interests involved, and moving towards an equalization of the treatment of photographs - at least when considered as single items - to the rules applicable to other objects possessing cultural interest, with a view toward ensuring greater enhancement of the Italian cultural heritage in all its expressions.

\footnotetext{
72 In Italy there has been a considerable increase in the establishment of departments dedicated to photographs within the main Italian auction houses: Finarte, Cambi, and II Ponte are focusing on the biggest Italian photographers such as Mario Giacomelli, Luigi Ghirri, Ugo Mulas, Franco Fontana. See N. Maggi, Fotografia: se il mercato italiano delle aste si fa in tre, "Collezione da Tiffany", 28 November 2018, https://www. collezionedatiffany.com/fotografia-se-il-mercato-italiano-delle-aste-si-fa-in-tre/ [accessed: 02.04.2019].

73 For a critical appraisal cf. A. Pirri Valentini, op. cit., pp. 9-13. In view of centralizing the administrative power and in order to guarantee greater certainty and uniformity in the application of general guidelines on export, on 19 June 2019 the President of the Council of Ministers approved the Decree on the reorganization of the MIBACT. The new regulation foresaw that export offices would have become "peripheral articulations of the Directorate General for Archaeology, Fine Arts and Landscape", and that the 18 export offices located in Italy would have been competent, ratione materiae, for the export of cultural properties whose owners reside in the area of competence of the export office. Following the crisis of the Italian government in August 2019, these new measures have been temporarily withdrawn. See G. Calabi, Meno Uffici Esportazione (non fidarsi è meglio?), "Il Giornale dell'Arte", July-August 2019, No. 399 and L. Casini, Linsostenibile leggerezza ovvero la "nuova" riorganizzazione del Ministero per i beni e le attività culturali (Mibac), "Istituto di ricerche sulla pubblica amministrazione", 20 June 2019, https://www.irpa.eu/linsostenibile-leggerezza-ovvero-la-nuova-riorganizzazione-del-ministero-per-i-beni-e-le-attivita-culturali-mibac/ [accessed: 17.07.2019].
} 


\section{References}

Ainis M., Fiorillo M., L'ordinamento della cultura, Giuffrè, Milano 2015.

Antonucci D., Codice commentato dei beni culturali e del paesaggio, Esselibri, Napoli 2009.

Arciero G., La fotografia nel diritto d'autore. I codici della fotografia, Nuova Arnica Editrice, Roma 1985.

ArtTactic, Photography Market Report 2017, https://arttactic.com/product/photography-market-2nd-half-2017/ [accessed: 06.10.2018].

Assini N., Cordini G., I beni culturali e paesaggistici: diritto interno, comunitario, comparato e internazionale, CEDAM, Padova 2006.

Barletta A., Art. 12, in: M.A. Sandulli (ed.), Codice dei beni culturali e del paesaggio, Giuffrè, Milano 2012.

Bate D., Art Photography, Tate Publishing, London 2015.

Blanchard B., Art contemporain, le paradoxe de la photographie, L'Harmattan, Paris 2014.

Boldon Zanetti G., Il nuovo diritto dei beni culturali, Cafoscarina, Venezia 2016.

Calabi G., Italy, in: P. Valentin (ed.), Art Law 2018, Law Business Research Ltd., London 2018, https://www.artatlaw.com/wp-content/uploads/2018/06/AL2018Engand-Wales.pdf [accessed: 12.10.2018].

Calabi G., Meno Uffici Esportazione (non fidarsi è meglio?), "II Giornale dell'Arte”, July-August 2019, No. 399.

Calabi G., Favero V., Progetto Apollo. Verso una riforma del mercato dell'arte, "Wannenes Art Magazine" 2017, Vol. 7(1), https://wannenesgroup.com/magazine/progetto-apollo-verso-una-riforma-del-mercato-dellarte/ [accessed: 28.09.2018].

Cammelli M., Il Codice dei beni culturali e del paesaggio: dall'analisi all'applicazione, "Aedon" 2004(2), http://www.aedon.mulino.it/ [accessed: 30.03.2019].

Cammelli M. (ed.), La nuova disciplina dei beni culturali e ambientali: commento al Testo Unico approvato con il decreto legislativo 29 ottobre 1999, n. 490, II Mulino, Bologna 2000.

Carpentieri P., Tutela e valorizzazione dei beni culturali, "Urbanistica e appalti” 2003(9).

Caruso G., Dichiarazione dell'interesse: dalla verifica al ricorso, "Guida al Diritto" 2004(4).

Case C-1/89, Ingrid Raab v. Hauptzollamt Berlin-Packhof, ECR, 1989, 4423.

Casini L., L'insostenibile leggerezza ovvero la "nuova" riorganizzazione del Ministero per i beni e le attività culturali (Mibac), "Istituto di ricerche sulla pubblica amministrazione", 20 June 2019, https://www.irpa.eu/linsostenibile-leggerezza-ovvero-la-nuova-riorganizzazione-del-ministero-per-i-beni-e-le-attivita-culturali-mibac/ [accessed: 17.07.2019].

Catelani A., La tutela dei beni culturali audiovisivi da parte dello Stato italiano, "Rassegna parlamentare" 2007(4).

Cerulli Irelli V., I beni culturali nell'ordinamento italiano vigente, in: M.P. Chiti (ed.), Beni culturali e Comunità Europea, Milano, Giuffrè 1994.

Chiti M.P., La nuova nozione di "beni culturali" nel d.Ig. 112/1998: prime note esegetiche, "Aedon" 1998(1), http://www.aedon.mulino.it/ [accessed: 06.10.2018].

Circolare Ministeriale 12 luglio 2018, n. 31 [Ministerial Circular No. 31 of 12 July 2018].

Clarke G., The Photograph. A Visual and Cultural History, Oxford University Press, Oxford 1997. 


\title{
GENERAL ARTICLES
}

\author{
Eliana Romanelli
}

Commissione d'indagine per la tutela e la valorizzazione del patrimonio storico, archeologico, artistico e del paesaggio, Per la salvezza dei beni culturali in Italia. Atti e documenti della Commissione d'indagine per la tutela e la valorizzazione del patrimonio storico, archeologico, artistico e del paesaggio, Colombo, Roma 1967.

Cortese W., I beni culturali e ambientali. Profili normativi, CEDAM, Padova 1999.

Costituzione della Repubblica Italiana [Constitution of the Italian Republic], Gazzetta Ufficiale No. 298, 27 December 1947.

Cotton C., La fotografia come arte contemporanea, Einaudi, Torino 2010.

Council Regulation (EC) No. 116/2009 of 18 December 2008 on the export of cultural goods (codified version), OJ L 39, 10.02.2009.

Council Regulation (EEC) No. 2658/87 of 23 July 1987 on the tariff and statistical nomenclature and on the Common Customs Tariff, OJ L 256, 7.09.1987.

Council Regulation (EEC) No. 3911/92 of 9 December 1992 on the export of cultural goods, OJ L 395, 31.12.1992.

Crippa A., Mercato e fotografia. Tempo di bilanci, "Artribune", 13 July 2018, https://www. artribune.com/professioni-e-professionisti/mercato/2018/07/fotografia-aste/ [accessed: 02.04.2019].

Decreto del Presidente del Consiglio dei Ministri 19 giugno 2019 [Decree of the President of the Council of Ministers of 19 June 2019], Gazzetta Ufficiale No. 199, 26 April 2019.

Decreto del Presidente della Repubblica 3 dicembre 1975, n. 805 "Organizzazione del Ministero per i beni culturali e ambientali" [Decree of the President of the Republic No. 805 of 3 December 1975 "Organization of the Ministry of Cultural Property and Activities"], Gazzetta Ufficiale No. 23, 27 January 1976.

Decreto Legislativo 22 gennaio 2004, n. 42 "Codice dei beni culturali e del paesaggio" [Legislative Decree No. 42 of 22 January 2004 "Cultural Heritage Code"], Gazzetta Ufficiale No. 45, 24 February 2004.

Decreto Legislativo 29 ottobre 1999, n. 490 "Testo unico delle disposizioni legislative in materia di beni culturali e ambientali a norma dell'articolo 1 della legge 8 ottobre 1997, n. 352" [Legislative Decree No. 490 of 29 October 1999 "Unified Text of cultural and landscape assets legislation, pursuant to Article 1 of the Law No. 352 of 8 October 1997], Gazzetta Ufficiale No. 302, 27 December 1999.

Decreto Legislativo 31 marzo 1998, n. 112 "Conferimento di funzioni e compiti amministrativi dello Stato alle regioni ed agli enti locali, in attuazione del capo I della Legge 15 marzo 1997, n. 59" [Legislative Decree No. 112 of 31 March 1998 "Conferral of functions and administrative tasks of the State to the Regions and local bodies, in implementation of chapter I of Law No. 59 of 15 March 1997"], Gazzetta Ufficiale No. 92, 21 April 1998.

Decreto Ministeriale 6 dicembre 2017, n. 537 "Indirizzi di carattere generale per la valutazione del rilascio o del rifiuto dell'attestato di libera circolazione da parte degli uffici esportazione delle cose di interesse artistico, storico, archeologico, etnoantropologico" [Ministerial Decree No. 537 of 6 December 2017 "General directions for issuing or refusing a certificate of free circulation by the Export Offices for objects of artistic, historical, archaeological, ethno-anthropological value"].

Decreto Ministeriale 9 luglio 2018, n. 305 "Condizioni, modalità e procedure per la circolazione internazionale di beni culturali. Decreto integrativo" [Ministerial Decree No. 305 of 9 July 2018 "Conditions, methods and procedures for the international circulation of cultural property. Supplementary decree"]. 
Dell'Arte S., Fotografia e diritto, UTET, Torino 2014.

Deloitte, ArtTactic, Art \& Finance Report 2017, Luxembourg 2017, https://www2.deloitte. com/lu/en/pages/art-finance/articles/art-finance-report.html [accessed: 31.03.2019].

Donati A., "Art as Idea as Idea". Diritto e creazione artistica contemporanea, "Quaderni del dottorato fiorentino in Scienze giuridiche" 2017.

Donati A., La definizione giuridica di opera d'arte e le nuove forme di espressione artistica contemporanea, "Rivista del Consiglio" 2017-2018.

Donati A., Nuovi criteri per il rilascio dell'attestato di libera circolazione, paper presented during the conference La circolazione dei beni culturali. I primi due anni della riforma, Milano, 9 April 2018.

Donati A., Rilevanza giuridica dell'archivio d'artista, in: Impresa Cultura. Creatività, partecipazione, competitività. XII Rapporto annuale Federculture, Gangemi, Roma 2016.

Foà S., La legittimità costituzionale della I. reg. Lazio sulla tutela e valorizzazione dei locali storici, "Giornale di diritto amministrativo" 2003(9).

Frigo M., La circolazione internazionale dei beni culturali. Diritto internazionale, diritto comunitario e diritto interno, Giuffrè, Milano 2007.

Hertzmann A., Can Computers CreateArt?, "Arts" 2018(7), https://arxiv.org/pdf/1801.04486. pdf [accessed: 08.04.2019].

International Bar Association, Art Law: Restrictions on the Export of Cultural Property and Artwork, November 2017, https://www.ibanet.org/Document/Default.aspx?DocumentUid=cba9a842-d0b8-4e73-952a-a00406416d5d [accessed: 12.10.2018].

Lafarge F., L'esportazione dei beni culturali dal territorio dell'Unione europea nel Testo Unico dei beni culturali, in: M. Cammelli (ed.), La nuova disciplina dei beni culturali e ambientali: commento al Testo Unico approvato con il decreto legislativo 29 ottobre 1999, n. 490, II Mulino, Bologna 2000.

Legge 1 giugno 1939, n. 1089 "Tutela delle cose di interesse artistico e storico" [Law No. 1089 of 1 June 1939 "Protection of things of artistic or historical interest"], Gazzetta Ufficiale No. 184, 8 August 1939.

Legge 22 aprile 1941, n. 633 "Protezione del diritto d'autore e di altri diritti connessi al suo esercizio" [Law No. 633 of 22 April 1941 "Protection of copyright and neighbouring rights"], Gazzetta Ufficiale No. 166, 16 July 1941.

Legge 4 agosto 2017, n. 124 "Legge annuale per il mercato e la concorrenza" [Law No. 124 of 4 August 2017 "Annual law on market and competition"], Gazzetta Ufficiale No. 189, 14 October 2017.

Lemme F., La tutela internazionale dei beni culturali e ambientali, in: N. Assini, P. Francalacci (eds.), Manuale dei beni culturali, CEDAM, Padova 2000.

Leonardi R., Esportazione dal territorio dell'Unione europea, in: M.A. Sandulli (ed.), Codice dei beni culturali e del paesaggio, Giuffrè, Milano 2012.

Lodolini E., Legislazione sugli archivi. Storia, normativa, prassi, organizzazione dell'amministrazione archivistica, Vols. I-II, Patron, Bologna 1998-2004.

Maggi N., Fotografia: se il mercato italiano delle aste si fa in tre, "Collezione da Tiffany", 28 November 2018, https://www.collezionedatiffany.com/fotografia-se-il-mercato-italianodelle-aste-si-fa-in-tre/ [accessed: 02.04.2019]. 


\title{
GENERAL ARTICLES
}

\author{
Eliana Romanelli
}

Maggi N., Report Mercato Fotografia: 2018 anno record per l'Italia, "Collezione da Tiffany", 27 March 2019, https://www.collezionedatiffany.com/report-mercato-fotografia2018-anno-record-per-litalia/ [accessed: 09.04.2019].

Magri G., La circolazione dei beni culturali nel diritto europeo: limiti e obblighi di restituzione, Edizioni Scientifiche Italiane, Napoli 2011.

Manacorda S., La circolazione illecita dei beni culturali nella prospettiva penalistica: problemi e prospettive di riforma, in: Circolazione dei beni culturali mobili e tutela penale: un'analisi di diritto interno, comparato e internazionale, Giuffrè, Milano 2015.

Manes V., La circolazione illecita dei beni artistici e archeologici. Risposte penali ed extrapenali a confronto, in: Circolazione dei beni culturali mobili e tutela penale: un'analisi di diritto interno, comparato e internazionale, Giuffrè, Milano 2015.

Manes V., La tutela penale, in: C. Barbati, M. Cammelli, G. Sciullo (eds.), Diritto e gestione dei beni culturali, II Mulino, Bologna 2011.

Marini F.S., I "beni culturali" ed i "locali storici" del Lazio: una differenza storico-normativa, "Giurisprudenza costituzionale" 2003(2).

Marsala H., II Ddl concorrenza è legge. Cosa cambia per arte e beni culturali, "Artribune", 3 August 2017, http://www.artribune.com/arti-visive/archeologia-arte-antica/2017/08/ politica-mercato-ddl-concorrenza-e-legge-cosa-cambiaper-arte-beni-culturali-polemiche/ [accessed: 28.09.2018].

Massaro A., Illecita esportazione di cose di interesse artistico: la nozione sostanziale di bene culturale e le modifiche introdotte dalla legge n. 124 del 2017, "Diritto penale contemporaneo" 2018(5).

McAndrew C., The Art Market 2017, Art Basel \& UBS, 2017, https://d33ipftjqrd91.cloudfront.net/asset/cms/Art_Basel_and_UBS_The_Art_Market_2017.pdf [accessed: 03.04.2019].

Menapace F., Una storia per immagini: la fotografia come bene culturale, Provincia Autonoma di Trento - Servizio beni culturali, Trento 1996.

Ministero per i beni e le attività culturali e per il turismo, Piano strategico di sviluppo della fotografia in Italia, 2018-2022, http://www.beniculturali.it/mibac/multimedia/MiBAC/ documents/1525355716796_Piano_Strategico_di_Sviluppo_della_Fotografia_in_Italia-1.pdf [accessed: 05.10.2018].

Mongillo R., Proprietà intellettuale ed opera fotografica, "Quaderni della Rivista di diritto dell'impresa" 2018.

Morbidelli G., Art. 10, in: M.A. Sandulli (ed.), Codice dei beni culturali e del paesaggio, Giuffrè, Milano 2012.

Morbidelli G., Art. 11, in: M.A. Sandulli (ed.), Codice dei beni culturali e del paesaggio, Giuffré, Milano 2012.

Otranto P., Commento agli artt. 73 e 74, in: A.M. Angiuli, V. Caputi Jambrenghi (eds.), Commentario al Codice dei beni culturali e del paesaggio, Giappichelli, Torino 2004.

Paderni M., Laboratorio Italia. La fotografia nell'arte contemporanea, Johan\&Levi, Milano 2009.

Perdonò G.L., L'uso illecito e le violazioni in materia di alienazione: riproposizione di vecchi schemi a fronte della rinuncia alle chances offerte dalle nuove frontiere della politica criminale, in: A. Manna, Il Codice dei beni culturali e del paesaggio. Gli illeciti penali, Giuffrè, Milano 2005. 
Pirri Valentini A., Il patrimonio culturale tra separazione dei poteri e controllo giurisdizionale: il caso dell'esportazione di opere d'arte, presentation at the AIPDA annual symposium 2018, http://www.diritto-amministrativo.org/index.php?page=42 [accessed: 06.04.2019].

Pitruzzella G., La nozione di bene culturale (artt. 1, 2, 3 e 4), “Aedon” 2000(1), http://www. aedon.mulino.it/ [accessed: 06.10.2018].

Puttemans A., Demarsin B., Les aspects juridiques de l'art contemporain, Larcier, Bruxelles 2013.

Rende A., Rolli R., Lo status giuridico dei beni culturali. Individuazione, vincoli ed incentivi, "Giustizia amministrativa" 2006(3).

Rizzo E., La fotografia come bene culturale, "Arte Ricerca", http://www.artericerca.com/ Fotografia/La\%20fotografia\%20come\%20Bene\%20culturale.html [accessed: 06.10.2018].

Rizzo E., La fotografia come documento del patrimonio, "Arte Ricerca", http://www.artericerca. com/Fotografia/La\%20fotografia\%20come\%20documento\%20del\%20patrimonio. html [accessed: 10.10.2018];

Roccella A., Manuale di legislazione dei beni culturali, Cacucci Editore, Bari 2017.

Rosenblum N., A World History of Photography, Abbeville Press, New York 1984.

Rositani N., Zannier I., La fotografia. Dall'immagine all'illecito nel diritto d'autore, Skira, Milano 2005.

Salamone F.E., Circolazione internazionale delle opere d'arte ed introduzione delle "soglie di valore": un'occasione da non sprecare, "News-Art", 19 February 2018, http://news-art.it/ news/circolazione-internazionale-delle-opere-d-arte-ed-introduzi.htm [accessed: 28.09.2018].

Sandulli M.A. (ed.), Codice dei beni culturali e del paesaggio, Giuffrè, Milano 2012.

Scharf A., Art and Photography, Penguin, Harmondsworth 1968.

Sciullo G., I beni, in: C. Barbati, M. Cammelli, G. Sciullo (eds.), Diritto e gestione dei beni culturali, II Mulino, Bologna 2011.

Sciullo G., La verifica dell'interesse culturale (art. 12), "Aedon" 2004(1), http://www.aedon. mulino.it/archivio/2004/1/art12.htm [accessed: 16.04.2019].

Sciullo G., Le funzioni, in: C. Barbati, M. Cammelli, G. Sciullo (eds.), Diritto e gestione dei beni culturali, II Mulino, Bologna 2011.

Sciullo G., Patrimonio e beni, in: C. Barbati et al. (eds.), Diritto del patrimonio culturale, II Mulino, Bologna 2017.

Sciullo G., Tutela, in: C. Barbati et al. (eds.), Diritto del patrimonio culturale, Il Mulino, Bologna 2017.

Severini G., Disposizioni generali, in: M.A. Sandulli (ed.), Codice dei beni culturali e del paesaggio, Giuffrè, Milano 2012.

Tamiozzo R., Il Codice dei Beni Culturali e del Paesaggio, Giuffrè, Milano 2004.

Tamiozzo R., La legislazione dei beni culturali e paesaggistici, Giuffrè, Milano 2014.

Tempesta G., La tutela dei beni culturali: aspetti di diritto italiano, di diritto canonico e dei trattati internazionali, in: T. Scovazzi (ed.), La restituzione dei beni culturali rimossi con particolare riguardo alla pratica italiana, Giuffrè, Milano 2014. 


\section{GENERAL ARTICLES}

Eliana Romanelli

Trapani M., Riflessioni a margine del sistema sanzionatorio previsto dal c.d. codice dei beni culturali, in: E. Battelli et al., Patrimonio culturale. Profili giuridici e tecniche di tutela, RomaTrE-Press, Roma 2017.

Trigari E., Il diritto nella fotografia - Diritto d'autore, privacy e altri diritti, Aracne, Roma 2013.

Valentin P. (ed.), Art Law 2018, Law Business Research Ltd., London 2018, https://www. artatlaw.com/wp-content/uploads/2018/06/AL2018Engand-Wales.pdf [accessed: 12.10.2018].

Vesperini G., Il silenzio nel regime dei beni culturali, “Aedon” 2006(2), http://www.aedon.mulino.it/archivio/2006/2/vesperini.htm [accessed: 16.04.2019].

Visconti A., The Reform of Italian Law on Cultural Property Export and its Implications for the "Definitional Debate": Closing the Gap with the European Union Approach or Cosmetics? Some Systemic Considerations from a Criminal Law Perspective, "Santander Art and Culture Law Review" 2019, Vol. 5(2).

Volpe G., Manuale di diritto dei beni culturali: storia e attualità, CEDAM, Padova 2013.

Zucchelli C., Artt. 13-16, in: M.A. Sandulli (ed.), Codice dei beni culturali e del paesaggio, Giuffrè, Milano 2012. 